HISTORY OF MEDICINE

\title{
Cocaine: a brief history on the discovery, popularisation and early use of medicinal cocaine
}

\author{
John H.Thompson* \\ Senior Clinical Fellow in Intensive Care Medicine, James Cook University Hospital, UK
}

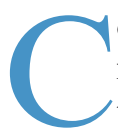
ocaine, the first true local anaesthetic, is derived from the leaves of the coca plant with its current therapeutic indications dwindling to a few ear, nose and throat procedures [1]. Today, its main use is as a drug of misuse, being the second commonest drug of misuse amongst adults aged 16-59 years in England and Wales [2]. However, it was not always just a drug of abuse and was favourably used by physicians in the past as an effective, and for some time the only, local anaesthetic.

History has revealed that occasionally, there can be a significant delay between a medical discovery and the recognition of its true therapeutic applications by medical practitioners. Joseph Priestley (1733-1804) identified nitrous oxide in 1772 , but it was not until the 1840 that Dr Horace Wells (1815-1848) would utilise its medicinal properties in dental anaesthesia [3,4]. Ether was discovered by Valerius Cordus in 1540 [5], and it was nearly 300 years, in 1846, before William Morton (1819-1868) promoted its anaesthetic application [6]. Both nitrous oxide and ether were initially used and abused in 'laughing gas parties' [7] in Britain and 'ether frolics' [8] in the United States, respectively. However, these very same parties permitted individuals to self-experiment and discover the potential therapeutic side-effects of these drugs and help promote their potential for medicinal application. This common theme amongst anaesthetic drug discovery is also seen in the story of cocaine.

\section{Discovery}

Cocaine is an ester-linked local anaesthetic alkaloid derived from the leaves of Erythroxylon coca, a shrub indigenous to Peru and Bolivia [1]. The stimulant effects of coca leaves were long appreciated by the ancient Incan people, thousands of years before the Spanish arrival in South America in the 16th century [9]. For the Andean people, it had two uses: first, a cultural symbol reserved for the societal elite, and second, its medicinal properties when chewed it provided pain relief and a stimulant for work and as a tea it was used for gastrointestinal upset.

Early documentation of its local anaesthetic benefits came from a Jesuit missionary, Bernabé Cobo (1582-1657), who was persuaded to chew on coca leaves to successfully alleviate his toothache instead of extracting the healthy tooth [10]. Italian neurologist Paolo Mantegazza (18311910) introduced coca leaves to the modern scientific community in 1858 and endorsed its use after observing its effects on the coca chewing South Americans [9]. The recognised medical benefit of coca leaves and its commercial potential led to a desire to extract and refine the active component [9].

Using ethanol as an extraction solvent, the tropane alkaloid, cocaine can be successfully extracted from raw coca leaves. The compound was first isolated in 1855 by Friedrich Gaedcke (1828-1890) and termed it as 'erythroxyline'. Albert Niemann (1834-1861) purified his compound in 1860, published his findings in his $\mathrm{PhD}$ dissertation 'Über eine neue organische Base in den Cocablättern' and called the substance 'cocaine' $[9,11]$.

\section{Popularisation}

After 1860, there was little interest in the anaesthetic application of cocaine. During the following two decades, experiments concentrated on the neurological and physiological effects of the drug and failed to recognise the therapeutic potential of its noted 'numbing' effect [12]. Cocaine's rise in popularity is thanks to a Corsican called Angelo Mariani (1838-1914), the world's first cocaine millionaire, with his popular tincture - coca wine or 'Vin Mariani'. Mariani came from a long line of physicians and chemists and was a habitual user of coca, convinced of its potential health benefits [13]. His interest in coca began following his reading of Mantegazza's publication [14]. He found that the most potent leaves were also the most bitter and, in an attempt to improve their taste, mixed them with Bordeaux wine. This mixing not only made consumption more palatable but also furthered the ethanol extraction of the active alkaloid, thus creating a more potent solution [11].

His 'Vin Mariani' was introduced in 1863 and proved to be extremely popular, eventually being sold world-wide [13]. He recommended his tincture as a cure-all for 'children and persons in delicate health' with the usual dose of 'one wine-glassful about an hour before or immediately after each meal; for children, half the quantity' [15]. He was 
not the first individual to sell coca wine, but he was the most successful due to an extremely effective advertising campaign that amassed a vast celebrity following and endorsement [16]. He had the support of international personalities such as Thomas Edison, Queen Victoria, Arthur Conan Doyle and even Pope Leo XIII and Pope Pius X [16]. Pope Leo was such a proponent of the wine that he awarded it a Papal gold medal, and his likeness was even used in Mariani's advertisements [14].

As part of these campaigns, Mariani sought the recommendation of physicians and claimed to have over 8,000 physician signatures endorsing his product [16]. One doctor who fully endorsed this cocainised wine was Sigmund Freud, who prescribed cocaine liberally for depression, digestive disorders, alcoholism and as a cure for opium addiction [9].

\section{Medicinal application}

Sigmund Freud (1856-1939), a recent Vienna graduate, experimented with coca on himself as a means to alleviate his opium addiction. He found the results to be so effective that he prescribed it liberally to himself and his patients, and in 1884, he published a paper 'Über Coca' [17]. Like others before him, he noted the numbing effects on his tongue but did not utilise these anaesthetic effects and, instead, suggested its use to his colleague and friend Karl Koller (1857-1944). Being encouraged by Freud, Koller experimented with cocaine on animals and himself and, eventually, performed his first surgery with cocaine local anaesthetic on 11 September 1884 to treat a patient's glaucoma [10]. Koller eventually presented his work to the Viennese Medical Society in October 1884 and published his results later that month. The impact of his discovery was instantly recognised, and by late 1885 , there were 60 publications from the United States and Canada about local anaesthesia and cocaine [10].

The excitement for this newly described anaesthesia would continue, and in August 1898, Bier (1861-1949) would perform the first spinal anaesthesia through an intrathecal injection of cocaine in what he called 'cocainisation of the spinal cord' [18]. Bier's first patient was a 34-year-old labourer who required a foot amputation but could not undergo general anaesthesia. Bier suggested spinal anaesthesia to him and successfully completed the surgery without pain. He performed a similar technique to five other patients before embarking on self-experimentation with his assistant Dr August Hildebrandt [19].

Hildebrandt attempted to perform a spinal anaesthetic on Bier; however, in the process, Hildebrandt struggled to attach the syringe to the needle hub causing Bier to lose a significant amount of cerebrospinal fluid. Most of the cocaine was lost before being injected, and Bier had no anaesthetic effect. Dr Hildebrandt volunteered to swap places. Bier successfully injected into Hildebrandt's intrathecal space and published a detailed summary of the effects of the spinal [19]. The anaesthetic lasted over 45 minutes, and during that time, Bier tested the efficacy of his block through a series of bizarre checks that included burning a cigar on Hildebrandt's legs, avulsion of his pubic hairs, striking his shin with a hammer and strong pressure and traction of the testicles. Delighted with their success, the men proceeded to 'dine and drink wine and smoke cigars' [19]. After the effects of the spinal wore off, both developed severe 'unpleasant after-effects', and Bier attributed the severity of their symptoms to the fact that they 'drank and smoked more than was good for us' [11]. Both men suffered from post-dural puncture headaches, and in his report, he described the classic symptoms, but Bier misattributed this to his wine 'hangover' rather than the large amount of cerebrospinal fluid they both lost.

\section{Aftermath}

Cocaine was liberally utilised in America, but in Europe, there was a much more conservative approach. Whilst initially advertised as relatively safe, doctors and dentists begin to notice an increase in toxic side-effects and addictive properties. By 1891, there were 13 reported associated deaths secondary to cocaine toxicity [20]. Cocaine usage become more reserved, and practitioners returned to their use of familiar anaesthetic gases, nitrous oxide and ether, for minor procedures. A novel safer drug was required to overcome these issues, and it would be found by a German chemist Alfred Einhorn (1856-1917) in 1904 with a drug called 'procaine' (also known as 'novocaine'). Results of its effectiveness were published in 1905, and soon, procaine had taken the place of cocaine as the 'go-to' local anaesthetic [10].

\section{Conclusion}

It was the work of Niemann in 1860 that allowed us to isolate the active component of the coca leaf. Its anaesthetic properties were not utilised initially, but its stimulant effects were exploited and widely used by the general public. Cocaine's popularisation was thanks to Mariani's production of Vin Mariani and due to his highly successful advertising campaign with his royal, papal and celebrity endorsement. His popularisation of coca wine captured the attention of a wider audience, including the medical community. Similar to other anaesthetic drugs, it was this increased use (and potential misuse) of cocaine that allowed others, such as Freud, to suggest alternative applications. Koller helped to change the face of medicine and dentistry when he successfully utilised cocaine as a local anaesthetic. Its short, but important, 21 years of use as a local anaesthetic paved the way for the development of newer and safer agents. 


\section{Conflict of interest and funding}

The authors have not received any funding or benefits from industry or elsewhere to conduct this study.

\section{References}

1. Peck TE, Hill SA. Pharmacology for anaesthesia and intensive care. In Chapter 11: Local anaesthetics. 4th ed. Cambridge: Cambridge University Press, 2014; pp. 164- 165.

2. Stripe N, ed. Drug misuse in England and Wales: year ending March 2020. Office for National Statistics: 2020. Available from: https://www.ons.gov.uk/peoplepopulationandcommunity/ crimeandjustice/articles/drugmisuseinenglandandwales/yearendingmarch2020 [cited 21 September 2021].

3. Yorkshire Philosophical Society. Joseph Priestley (1733-1804) A grand tour. Available from: https://www.ypsyork.org/resources /yorkshire-scientists-and-innovators/joseph_priestley/ [cited 30 November 2020].

4. Lew V, McKay E, Maze M. Past, present, and future of nitrous oxide. Br Med Bull 2018; 125: 103-19. doi: 1093/bmb/ldx050

5. Duncum BM. Ether anaesthesia 1842-1900. Postgrad Med J 1946; 22: 280-90. doi: 10.1136/pgmj.22.252.280

6. Desai SP, Desai MS, Pandav CS. The discovery of modern Anaesthesia - contributors of Davy, Clarke, Long, Wells and Morton. Indian J Anaesth 2007; 51: 472-6.

7. Zuck D, Royal Society of Chemistry. Nitrous oxide: are you having a laugh? Available from: https://edu.rsc.org/feature/ nitrous-oxide-are-you-having-a-laugh/2020202.article [cited 30 November 2020].

8. Cartwright F. The early history of ether. Anaesthesia 1960; 15: 67-9. doi: 1111/j.1365-2044.1960.tb13901.x

9. Bauer I. Travel medicine, coca and cocaine: demystifying and rehabilitating Erythroxylum - a comprehensive review. Trop Dis Trav Med Vaccine 2019; 5: 1-14. doi: 10.1186/s40794019-0095-7

10. Calatayud J, González A. History of the development and evolution of local anesthesia since the coca leaf. Anaesthesiology 2003; 98: 1503-8. doi: 10.1097/00000542-200306000-00031
11. Dronsfield A, Ellis P. Cocaine - a short trip in time. Available from: https://edu.rsc.org/feature/cocaine-a-short-trip-in-time/ 2020119.article [cited 30 December 2020].

12. Gootenberg P. Andean cocaine: the making of a global drug. Chapel Hill, NC: The University of North Carolina Press; 2008.

13. De Lestrange A. Coca Wine: Angelo Mariani's miraculous elixir and the birth of modern advertising. Rochester, Vermont: Park Street Press; 2018. Chapter: Angelo Mariani, Father of Coca Wine - The Beginnings of Vin Mariani, Which Would Become the Most Popular Prescribed Medicine in the World. Park Street Press Rochester, Vermont.

14. Botes M. Vin Mariani - Saint or sinner?: intellectual property. Without Prejudice 2012; 12: 33-4.

15. Mariani \& Company. Coca Erythroxylon (Vin Mariani): its uses in the treatment of disease: with notes and comments by prominent physicians. 4th ed. Paris: Mariani \& Co; 1886. Available from: https://wellcomecollection.org/works/ hm779p6q [cited 26 May 2021].

16. Emery E. Viral marketing: Mariani Wine testimonials in Early French and American newspaper advertising. Nineteenth-Century Contexts 2017; 39: 117-29. doi: doi: 10.1080/08905495.2017.1284567

17. Nathan J, Asadourian L, Erlich MA. A brief history of local anaesthesia. IJHNS 2016; 7: 29-32. doi: 10.5005/jp-journals10001-1261

18. Wulf HFW. The centennial of spinal anesthesia. Anaesthesiology 1998; 89: 500-6. doi: doi: 10.1097/00000542-199808000-00028

19. Bier A. Versuche über Cocainisirung des Rückenmarkes. Deutsche Zeitschrift für Chirurgie 1899; 51: 361-9. doi: 10.1007/BF02792160

20. Petersen RC, Corfman EL, editors. Cocaine: 1977 - NIDA research monograph \#13. In Chapter 1: History of cocaine. Washington, DC: U.S. Government Printing Office, 1977; pp. 17- 34.

\footnotetext{
*John H.Thompson

Intensive Care

James Cook University Hospital,

Middlesbrough, UK.

Email: jack.thompson8@nhs.net
} 